Case Study

\title{
Indirect estimate of in loco moisture via normative mineralogy calculation with correction of seasonal effect on itabirite (banded iron formation) of the Pico complex, Quadrilátero Ferrífero, Minas Gerais, Brazil
}

\author{
Giulia Marina Cerqueira Dias ${ }^{1} \mathbb{D} \cdot$ Daniel Quinaud Rossi ${ }^{1} \cdot$ Diniz Ribeiro $^{2}$
}

Received: 21 May 2021 / Accepted: 1 October 2021

Published online: 21 November 2021

(c) The Author(s) 2021 OPEN

\begin{abstract}
Moisture is a critical variable in iron-ore processing, handling and transportation. During beneficiation, excessive moisture may lead to screen and chute clogging. In transportation, moisture values above transportable moisture limit may cause cargo instabilities, especially in regard to vessels. Moisture is a non-stationary variable that depends on spatial and time distributions. Therefore, classical estimate methods such as ordinary kriging are not appropriate to calculate moisture values. Here, we present an extension of the Normative Mineralogy Calculation to indirectly estimate moisture, considering seasonal influence. This study in based on three iron-ore mines, Galinheiro, Pico and Sapecado. They are located in the Quadrilátero Ferrifero of Minas Gerais, Brazil, a world-class iron-ore district. The method proposed herein provides useful information that can be applied elsewhere. Our results indicate that compact ores show low moisture values with little seasonal influence, while soft ores and canga (iron-rich duricrust) are strongly influenced seasonally due to higher porosity and greater capacity of retaining water in the crystal structure of minerals, such as goethite. Moisture variations may exceed $2 \%$ along the year. Such variations are enough to preclude the beneficiation of certain iron ores during the rainy season. For this reason, moisture has been regarded as an essential variable in short-term mining.
\end{abstract}

\section{Article Highlights}

- Moisture is a critical variable in iron-ore processing, handling and transportation. Moisture depends on spatial and time distributions; hence classical methods are not appropriate to quantitatively estimate it. This study proposes an indirectly estimate of moisture considering seasonal influence.
- Compact iron ores are little influenced seasonally, while soft iron ores and canga (duricrust) are strongly affected by the rainy season due to their higher porosity and greater capacity of retaining water.

- The seasonal effect on moisture is an essential variable that must be consider to better effectiveness of ironore mining sequencing and beneficiation.

Keywords Moisture · Iron ore · Itabirite (Banded iron formation, BIF) · Indirect estimation · Mineralogical normative calculation

Giulia Marina Cerqueira Dias, Giulia.dias@vale.com; Daniel Quinaud Rossi, Daniel.rossi@vale.com; Diniz Ribeiro, diniz.ribeiro@vale.com | ${ }^{1}$ Vale S.A., Iron Resource Management, Vargem Grande Complex, Nova Lima, MG 34.006-200, Brazil. 2 Vale S.A., Iron Resource Management, Águas Claras Office, Nova Lima, MG 34.006-200, Brazil. 


\section{Introduction}

The Quadrilátero Ferrífero (QF) is one of the largest ironore mining districts in the world, with estimated reserves of about $6.0 \mathrm{Gt}$ [1]. Galinheiro, Pico and Sapecado are three iron-ore mines that are located in the eastern portion of the QF (owned by VALE). They produced about 18 million (metric) tons in 2020. The main product is natural moisture sinter feed. Moisture is a critical variable in ironore processing and transportation. During beneficiation, excessive moisture makes iron ores adherent to walls and screens, leading to clog-related production delays. Moisture values above the transportable limit (TML) may also generate instabilities during transportation, especially in vessels.

Being a non-stationary variable, moisture depends on spatial and time distributions. Consequently, classical estimate methods such as ordinary kriging are not appropriate to calculate moisture. The Normative Mineralogy Calculation proposed by Motta et al. [2] for iron ores of the Quadrilátero Ferrífero could be used as an indirect way to estimate moisture from porosity, mineral density and natural density. This study presents an extension of the Normative Mineralogy Calculation to estimate run-of-mine (ROM) moisture, applying a monthly (seasonal) correction to moisture estimation.

\subsection{Geological context}

The Quadrilátero Ferrífero has world-class iron-ore deposits that are hosted in itabirite, a metamorphosed banded iron formation (BIF). The study areas, the mines Galinheiro, Pico and Sapecado, are located in the eastern portion of the Quadrilátero Ferrífero (Fig. 1), near the town of Itabirito, about $50 \mathrm{~km}$ from Belo Horizonte, the capital of the state of Minas Gerais. The mines are in the overturned southeast limb of the Moeda syncline and comprise rocks of the Minas Supergroup-i.e., the Moeda Formation and the Batatal Formation of the Caraça Group, and the overlying Itabira Group that consists of the Cauê Itabirite and the Gandarela Formation [3]. Post-Minas rocks include intrusive bodies and an iron-rich duricrust (canga). Previous studies described their iron-ore deposits as either weathering products of itabirite rocks, which formed friable contaminated ores (soft ore), or as the result of hydrothermal overprint, which gave rise to compact hematite (hard ore) $[4,5]$. The iron-ore mineralization of the study areas is subdivided into 10 ore types, on the basis of chemical and mineralogical compositions: compact itabirite (IC), friable itabirite (IF), aluminous itabirite (IAL), manganiferous itabirite (IMN), high-grade friable itabirite (IFR), friable hematite (HF), compact hematite (HC), goethite-hematite
(HGO), aluminous hematite (HAL) and canga (CG). Barren lithotypes are dolomite (DO), phyllite (FL), dolomitic phyllite (FD), intrusive rocks (IN) and laterite (LT).

\subsection{Climate conditions}

The study areas are between 1200 and $1580 \mathrm{~m}$ above the sea level, in the highlands of the Quadrilátero Ferrífero, the major ridges of which are as follows (Fig. 1): Serra do Curral (to the north), Serra da Moeda (to the west), Serra do Ouro Branco (to the south), Serra do Gandarela (to the northeast) and Serra do Caraça (to the east). These ridges are physical barriers to moisture transportation, generating local differences in terms of rainfall and temperature according to altitude [6]. The Quadrilátero Ferrífero has in general a mesothermal tropical climate, with most intense rainfall during late spring and summer (November to March), warm summers and dry winters-i.e., average temperature in the warmest month is about $22^{\circ} \mathrm{C}$, whereas average temperature in the coolest month is about $17^{\circ} \mathrm{C}$. Between 2014 and 2020, a gage station at the Pico mine recorded monthly minimum rainfall of $0 \mathrm{~mm}$ and maximum of $512 \mathrm{~mm}$. Figure 2 shows monthly pluviosity fluctuations obtained from rainfall data that were recorded for 7 years.

\section{Methods}

\subsection{Mineralogical normative calculation}

The Mineralogical Normative Calculation (MNC), proposed in early 1900s for igneous rocks [7], was adapted to the mineral assemblage of itabirite-hosted iron ores of the Quadrilátero Ferrífero, taking into account the distribution of minerals in weathering profiles $[2,8,9]$. The MNC uses elemental abundances, obtained from whole-rock chemical analyses, to calculate mineral proportions and, indirectly, mineral densities $[2,8,9]$. The method basically has two stages:

1 Definition of the main mineral assemblage, which comprises variable amounts of hematite, goethite and magnetite, and subordinate minerals, such as kaolinite, quartz, pyrolusite, talc, wavellite, apatite and gibbsite.

2 Calculation of mineral proportions in each sample from whole-rock chemical analyses of oxide components $\left(\mathrm{Fe}_{2} \mathrm{O}_{3}, \mathrm{FeO}, \mathrm{Al}_{2} \mathrm{O}_{3}, \mathrm{SiO}_{2}, \mathrm{P}_{2} \mathrm{O}_{5}, \mathrm{MgO}\right.$ and total $\mathrm{Mn}$ as $\mathrm{MnO}_{2}$ ) and loss on ignition (LOI).

A simplified sequence of the normative calculation, which is detailed in $[2,9]$, consists of the following steps: 


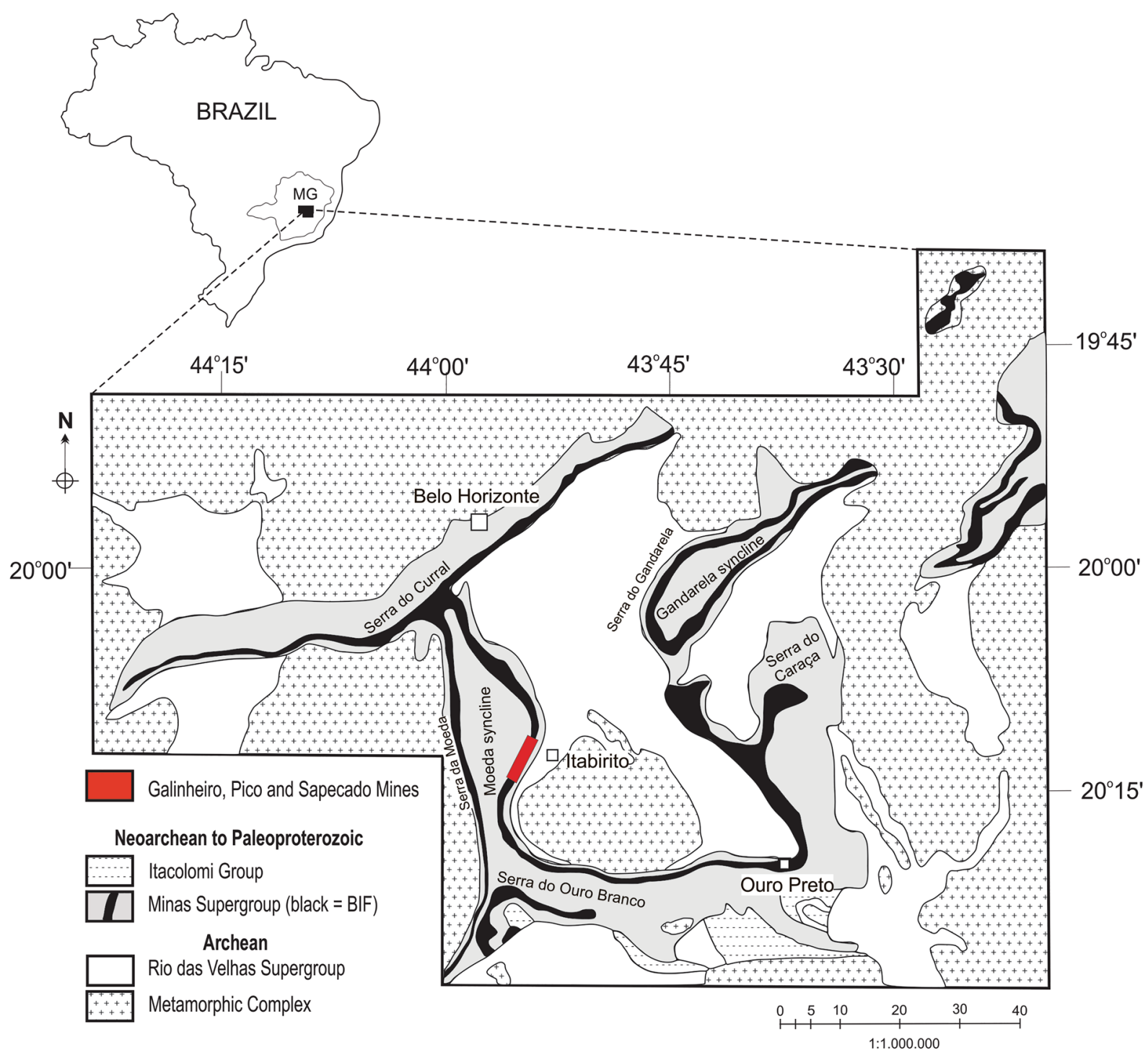

Fig. 1 Simplified geological map of the Quadrilátero Ferrífero, modified from Dorr et al. [6], showing the location of the study areas, Galinheiro, Pico and Sapecado mines. Inset abbreviation: BIF = Banded Iron Formation; MG = Minas Gerais State

i. Proportion of magnetite from $\mathrm{FeO}$ content- $-\mathrm{Fe}_{-} \mathrm{i}$ residual;

ii. Proportion of gibbsite from LOI and $\mathrm{Al}_{2} \mathrm{O}_{3}$ contents_-LOI_i and $\mathrm{Al}_{2} \mathrm{O}_{3}$ i i residual;

iii. Proportion of kaolinite from $\mathrm{LOI}_{-} \mathrm{i}, \mathrm{Al}_{2} \mathrm{O}_{3} \mathrm{i}$ and $\mathrm{SiO}_{2}$ contents- $\mathrm{SiO}_{2}$ i and LOI_ii residual;

iv. Proportion of quartz from $\mathrm{SiO}_{2} \mathrm{i}$ content;

v. Pyrolusite from total Mn content;

vi. Goethite from Fe_i and LOI_ii contents-Fe_ii residual;

vii. Hematite from Fe_ii content.

The MNC algorithm uses trial and error functions to distribute elemental concentrations among minerals to obtain totals close to $100 \%$ [2]. Absolute density or mineral density is obtained from the proportion of each mineral and its respective density (Fig. 3).

\subsection{Bulk density, natural density and porosity}

Bulk density $\left(\rho_{s}\right)$ corresponds to mineral mass on dry basis plus volume of pores and null saturation. Natural density $\left(\rho_{n}\right)$ is the ratio between the sample mass $(m)$ on wet basis and its volume (v) - i.e., bulk density plus saturation (volume of pores filled with water). The relationship among densities, porosity and saturation is illustrated in Fig. 4.

As proposed by Ribeiro et al. [9], total porosity ( $\phi)$ of samples can indirectly be obtained through the relationship between bulk density $\left(\rho_{\mathrm{s}}\right)$ and mineral density $\left(\rho_{\mathrm{m}}\right)$ : 
Monthly rainfall ( $\mathrm{mm})$

Pico Mine gage station

Analysis timeframe: 2014 to 2020

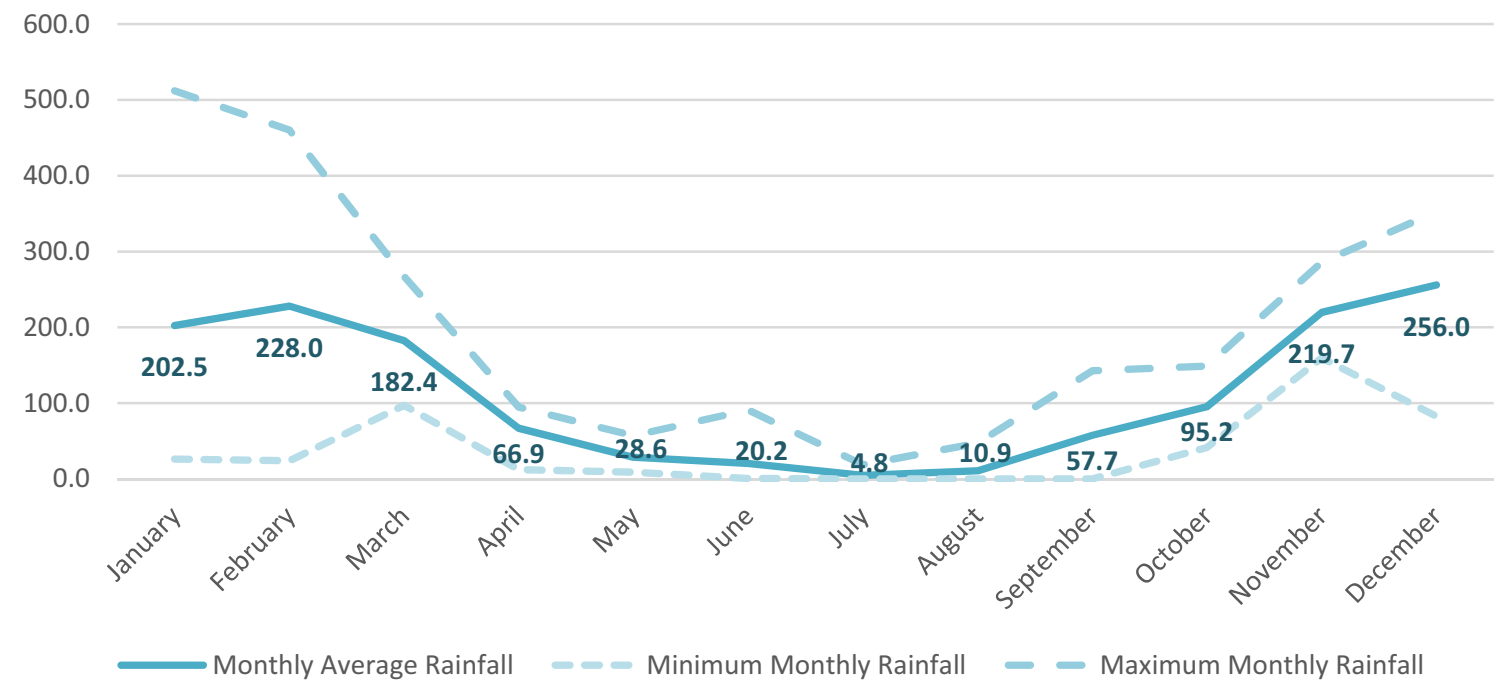

Fig. 2 Monthly average rainfall (continuous line); dotted lines repspond to the period between January 01, 2014 and December 31, resent the minimum and the maximum monthly value recorded 2020, and they were measured in the gage station at the Pico mine in the period. Source of data: Vale, internal report. Statistics corre-

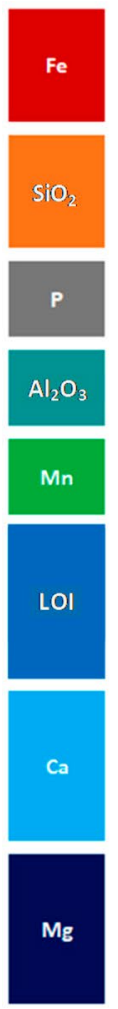

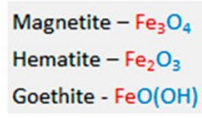

Magnetite $-\mathrm{Fe}_{3} \mathrm{O}_{4}$

Hematite $-\mathrm{Fe}_{2} \mathrm{O}_{3}$

Goethite - $\mathrm{FeO}(\mathrm{OH})$

Quartz- $\mathrm{SiO}_{2}$

Kaolinite - $\mathrm{Al}_{2} \mathrm{Si}_{2} \mathrm{O}_{5}(\mathrm{OH})_{4}$

Talc $-\mathrm{Mg}_{3} \mathrm{Si}_{4} \mathrm{O}_{10}(\mathrm{OH})_{2}$

Apatite $-\mathrm{Ca}_{5}\left(\mathrm{PO}_{4}\right)_{3}(\mathrm{OH})$

Wavellite $-\mathrm{Al}_{3}(\mathrm{OH}, \mathrm{F})_{3}\left(\mathrm{P}_{2} \mathrm{O}_{4}\right)_{2} \cdot 5 \mathrm{H}_{2} \mathrm{O}$

Kaolinite - $\mathrm{Al}_{2} \mathrm{Si}_{2} \mathrm{O}_{5}(\mathrm{OH})_{4}$

Gibbsite - $\mathrm{Al}(\mathrm{OH})_{3}$

Pyrolusite $-\mathrm{MnO}_{2}$

Goethite - $\mathrm{FeO}(\mathrm{OH})$

Kaolinite - $\mathrm{Al}_{2} \mathrm{Si}_{2} \mathrm{O}_{5}(\mathrm{OH})_{4}$

Gibbsite - $\mathrm{Al}(\mathrm{OH})_{3}$

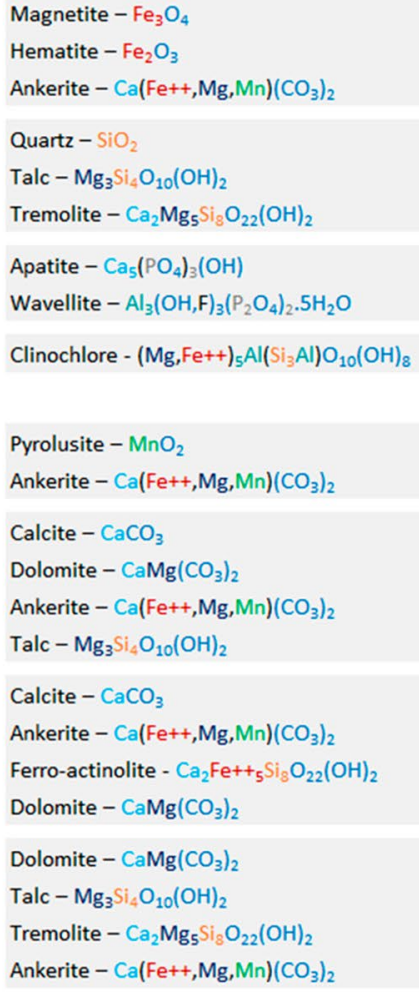

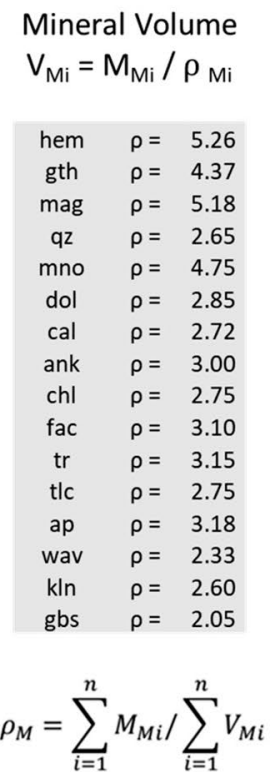

Fig. 3 Method of calculateion of mineral density from mineral proportion using MNC; extracted from Ribeiro et al. [9]

\section{SN Applied Sciences}




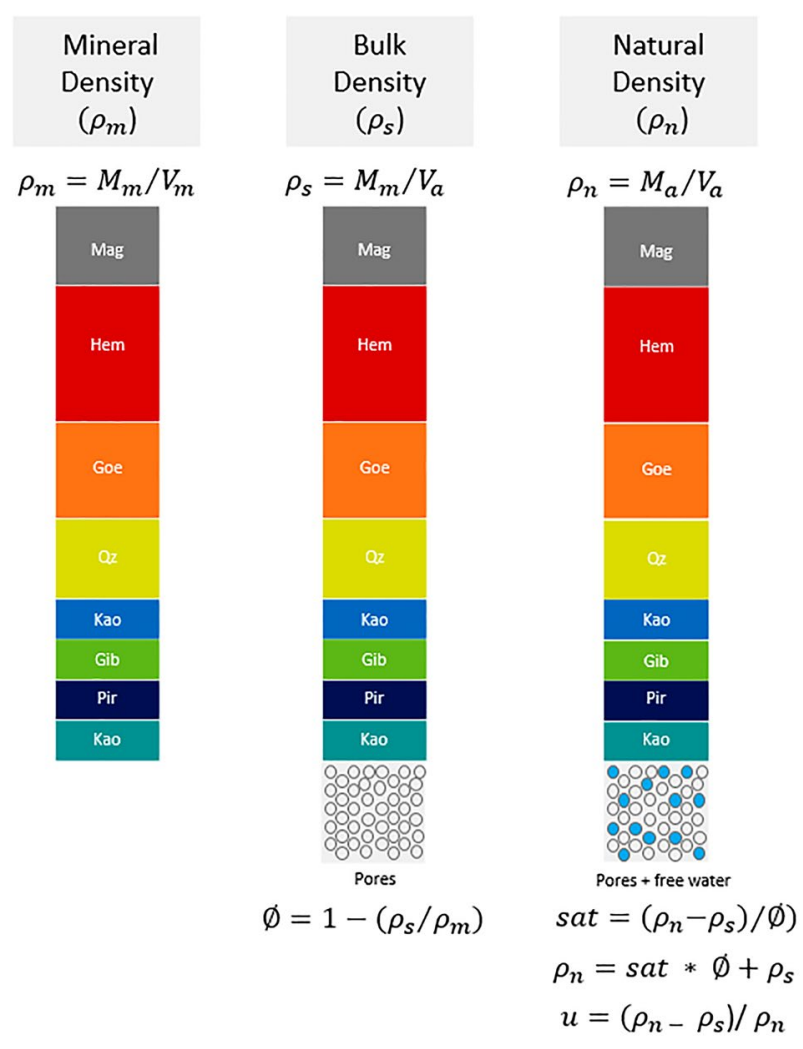

Fig. 4 Relationship among densities, porosity and saturation. Legend: $\rho_{\mathrm{m}}=$ Mineral density; $M_{\mathrm{m}}=$ Mineral mass; $\mathrm{V}_{\mathrm{m}}=$ Mineral volume; $\rho_{\mathrm{s}}=$ Bulk density; $\rho_{\mathrm{n}}=$ Natural density; $M_{\mathrm{a}}=$ Sample mass; $V_{\mathrm{a}}=$ Sample volume; $\phi=$ Porosity; sat $=$ Saturation; $u=$ Moisture

$\phi=1-\frac{\rho_{s}}{\rho_{m}}$

Fig. 5 Relationship among mineral density, bulk density and porosity. The latter is expressed as linear regressions in the range of $0 \%$ porosity (thin straight line) to $50 \%$ porosity (dashed lines), and for friable (weathered) and compact (unweathered) ore samples from the Quadrilátero Ferrífero; adapted from Motta et al. [2]
Through linear regression involving $\rho_{\mathrm{s}}$ and $\rho_{\mathrm{m}^{\prime}}$ it is possible to obtain coefficients for porosity. Figure 5 shows the results of samples from different iron-ore mines in the Quadrilátero Ferrífero [2]. The larger the angular coefficient, the lower the porosity, which increases from unweathered to weathered ores. The latter, also referred to as soft ores, comprise friable itabirite (IF), aluminous itabirite (IAL), manganiferous itabirite (IMN), high-grade friable itabirite (IFR), friable hematite (HF), goethite-hematite (HGO), aluminous hematite (HAL) and canga (CG), while unweathered ores are given by compact itabitite (IC) and compact hematite $(\mathrm{HC})$. Unweathered ores are characteristically hard. ${ }^{3}$

Samples are sieved for classification of particles sizes to define the percentual of grains withheld in three different sieves, progressively reducing the mesh size $(6.3 \mathrm{~mm}$, $1.0 \mathrm{~mm}$ and $0.15 \mathrm{~mm}$ ). Sizable particles are those larger than $6.3 \mathrm{~mm}$ and their percentage value in relation to the total mass of the sample is stored in variable G1. The same procedure is performed for the smaller meshes, thus the particle size distribution of samples is described by the percentage in each range: $\mathrm{G} 1$ corresponds to particles larger than $6.3 \mathrm{~mm}, \mathrm{G} 2$ are particles smaller than $6.3 \mathrm{~mm}$ and larger than $1.0 \mathrm{~mm}, \mathrm{G} 3$ represents particles smaller than $1.0 \mathrm{~mm}$ and larger than $0.15 \mathrm{~mm}$ and G4, smaller than $0.15 \mathrm{~mm}$. The sum of these four variables $\mathrm{G} 1, \mathrm{G} 2, \mathrm{G} 3$ and G4 must be $100 \%$, with $2 \%$ deviation tolerance. Samples that present granulometric totals outside the tolerance limits are excluded from the database.

Compact or unweathered ores are those that have more than $50 \%$ of the sample mass retained in the mesh sieve of $6.3 \mathrm{~mm}$-i.e., G1 is greater than $50 \%$. Samples that have more than $50 \%$ of mass passing through the mesh sieve of

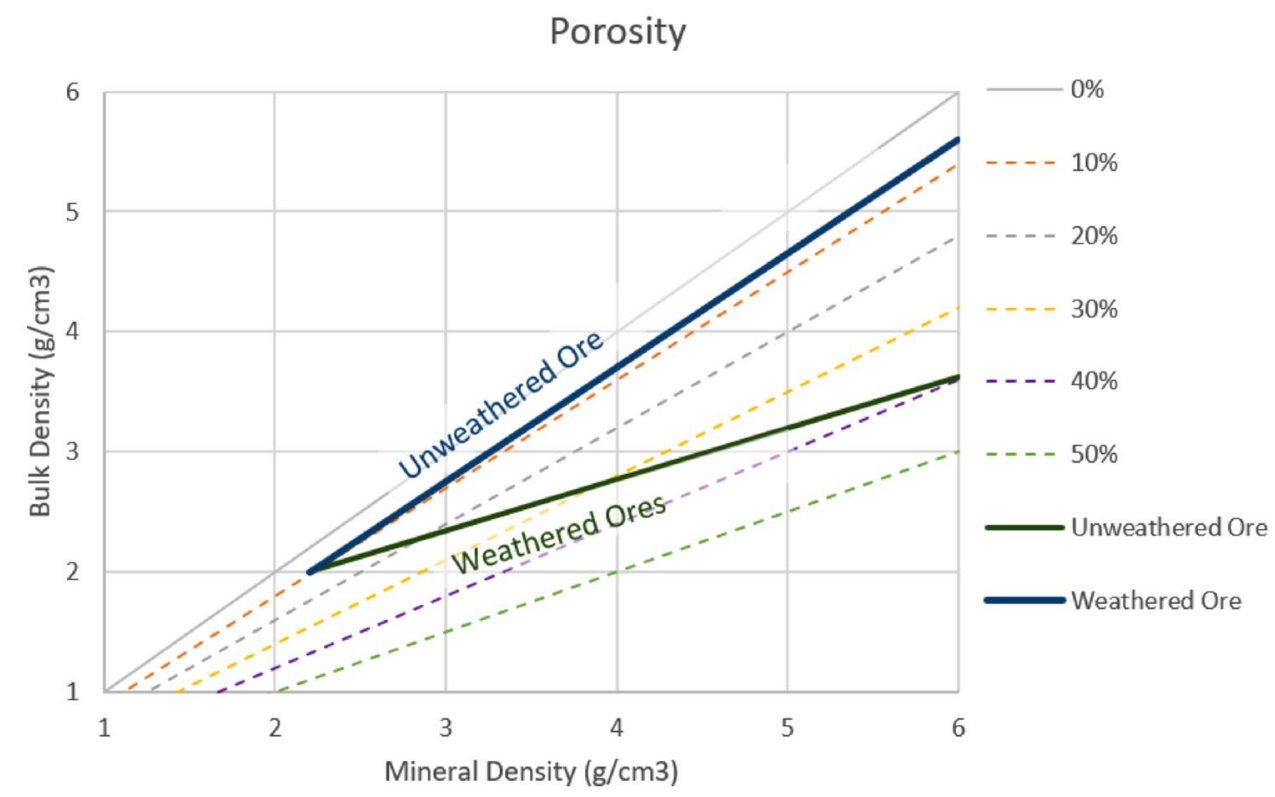

SN Applied Sciences 
$6.3 \mathrm{~mm}$ are considered as weathered or soft ore-i.e., the sum of G2, G3 and G4 is greater than $50 \%$. The smaller the particle size, the greater the porosity of the sample. Thus, high $\mathrm{G} 1$ values indicate that the rock is cohesive and massive, with low porosity. In contrast, low $\mathrm{G} 1$ values indicate that the particles are small and unconsolidated, increasing porosity. Mineral density $\left(\rho_{\mathrm{m}}\right)$ is obtained for compact and soft materials separately. It follows that $\mathrm{G} 1$ is the proportion of compact materials and $\rho_{1}$ is the absolute density of compact materials, whereas $\mathrm{G} 234$ is the sum of $\mathrm{G} 2, \mathrm{G} 3$ and G4-i.e., the proportion of soft materials-and $\rho_{234}$ is the absolute density of soft materials. Figure 6 contains the flowchart of the method to estimate the moisture from MNC using porosity regression equations according to the proportion of soft and compact materials.

Bulk-density and porosity data enable estimates of moisture values from fixed saturation percentages $(25 \%$, $50 \%, 75 \%$ and $100 \%)$. These values are compared with the results obtained from direct measurements to validate the method and adjust the variable saturation per lithotype.

\subsection{Effect of seasonality}

To assess the effect of seasonality, moisture results from channel samples and diamond-drill-hole samples were compared. Due to the long time gap between collection and sampling (average of 75 days and median of 22 days), and the lack of an inert storage, drill-hole samples presented moisture values in average $66 \%$ lower than channel samples. Channel samples are stored in sealed bags and have shorter time gaps between collection and sampling (average of 22 days and median of 8 days). For this reason, only channel samples were selected to model the effect of seasonality.

Database validation included checks for chemical and particle-size totals, other chemical components and extreme values-i.e., samples that are above $2 \%$ tolerance for totals or have moisture content above $25 \%$ of sample mass. Samples with extreme values were excluded from the database. After validation, the database consisted of 10,410 channel samples that were monthly collected for 8 years, from January 2012 to January 2020.

In order to simplify the modeling, lithotypes were combined into four groups on the basis of ore grade, compactness and geological formation environment:

- Compact ore has at least 50\% G1 (lithotypes IC and HC);

- Soft ore is lower than $50 \% \mathrm{G1}$, with low contents of contaminants-i.e., $\mathrm{Al}_{2} \mathrm{O}_{3}<3.5 \%, \mathrm{MnO}_{2}<2 \%$, $\mathrm{LOI}<3.5 \%$ (lithotypes IF, IFR and HF);

- Contaminated ores are characterized by contents of $\mathrm{Al}_{2} \mathrm{O}_{3}>3.5 \%, \mathrm{MnO}_{2}>2 \%$ or LOI $>3.5 \%$ (lithotypes IGO, IAL, HGO, HAL and IMN);

- Canga ore represents the iron duricrust over the main orebody, formed by exogenous processes, and usually

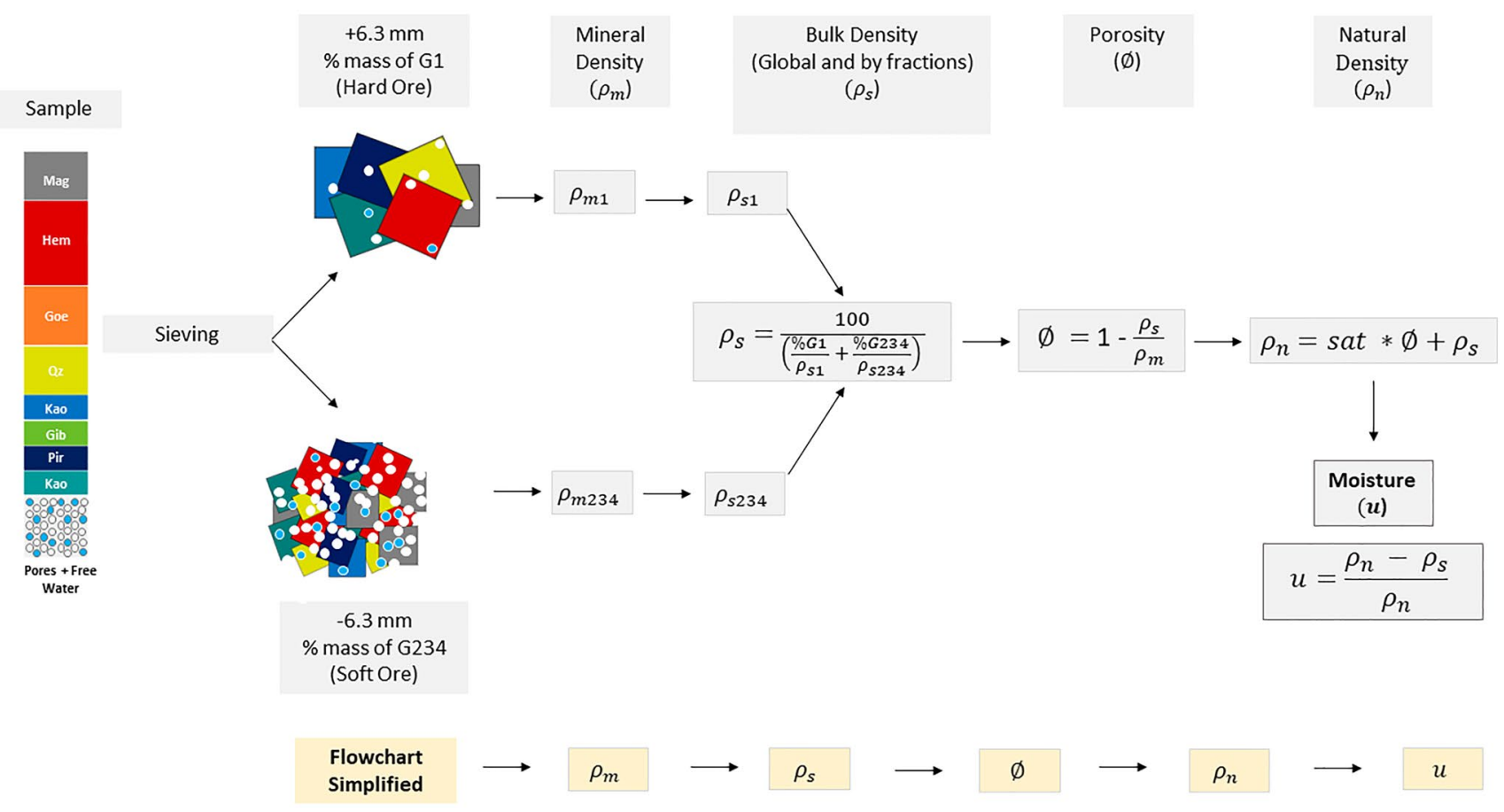

Fig. 6 Flowchart of the moisture estimate method using MNC 

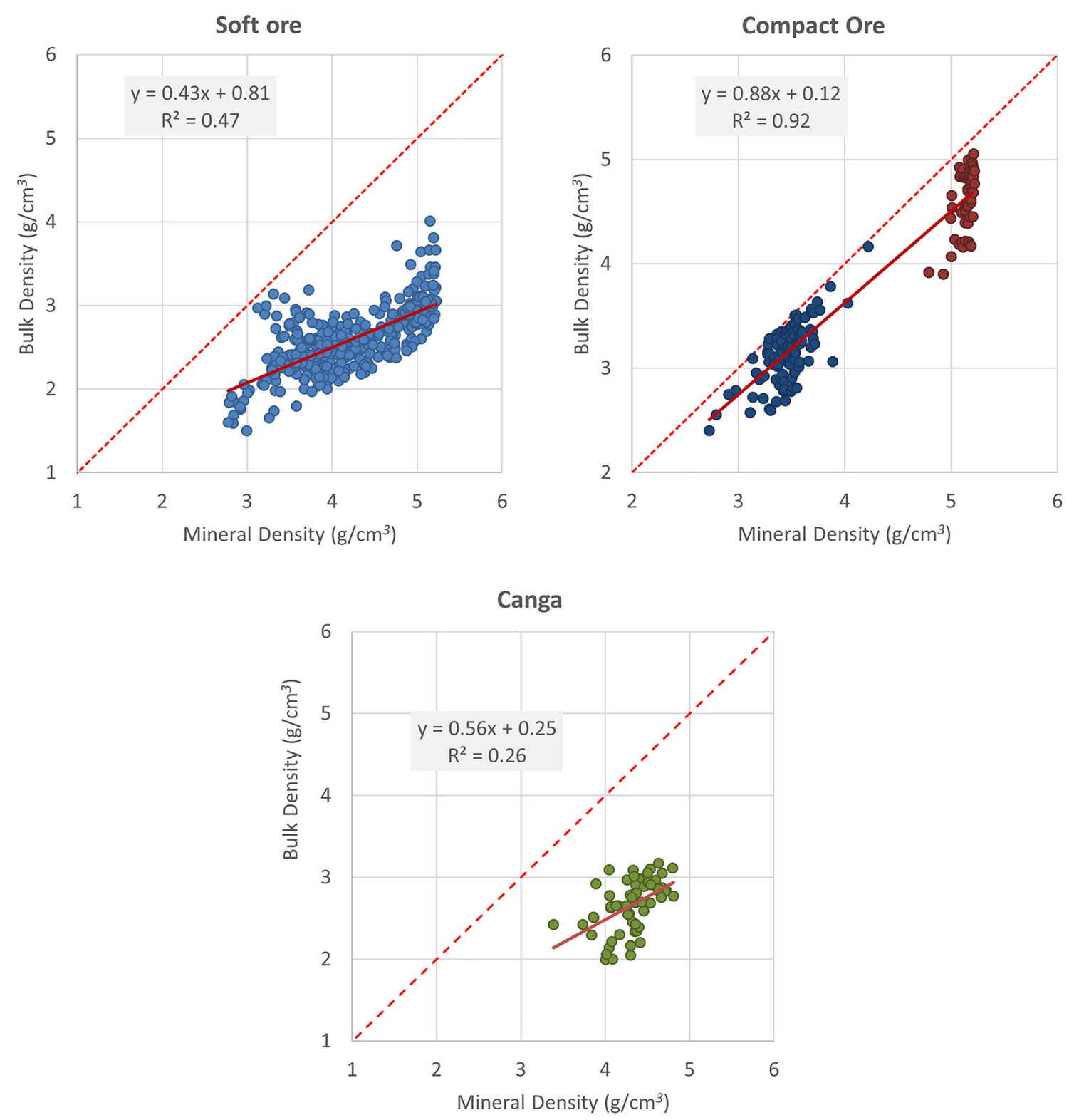

Fig. 7 Relationship between mineral density and bulk density for Galinheiro and Sapecado samples, for which natural and bulk density was directly measured. Compact ore presents two clusters,

has high porosity (above 30\%) and contents of $\mathrm{Al}_{2} \mathrm{O}_{3}$ and LOI above $3.5 \%$ (lithotype CG).

Monthly values were then normalized to the annual average, depicted as a general graph for all samples of moisture monthly variation, showing enrichment or impoverishment of moisture values along the year. The seasonal effect, defined as high moisture in the rainy season and low moisture in the dry season, is mathematically expressed as a third-order polynomial regression using the normalized monthly moisture database. The seasonal samples of low-grade ores are colored of blues and samples of high-grade ores are colored of red

effect was used to correct the average moisture value estimated using MNC depending on the month of the year.

\section{Results and discussion}

\subsection{Porosity}

The database used for modeling the linear regression of porosity contains 579 samples for which density were directly measured. The most used methods at Vale S.A. 


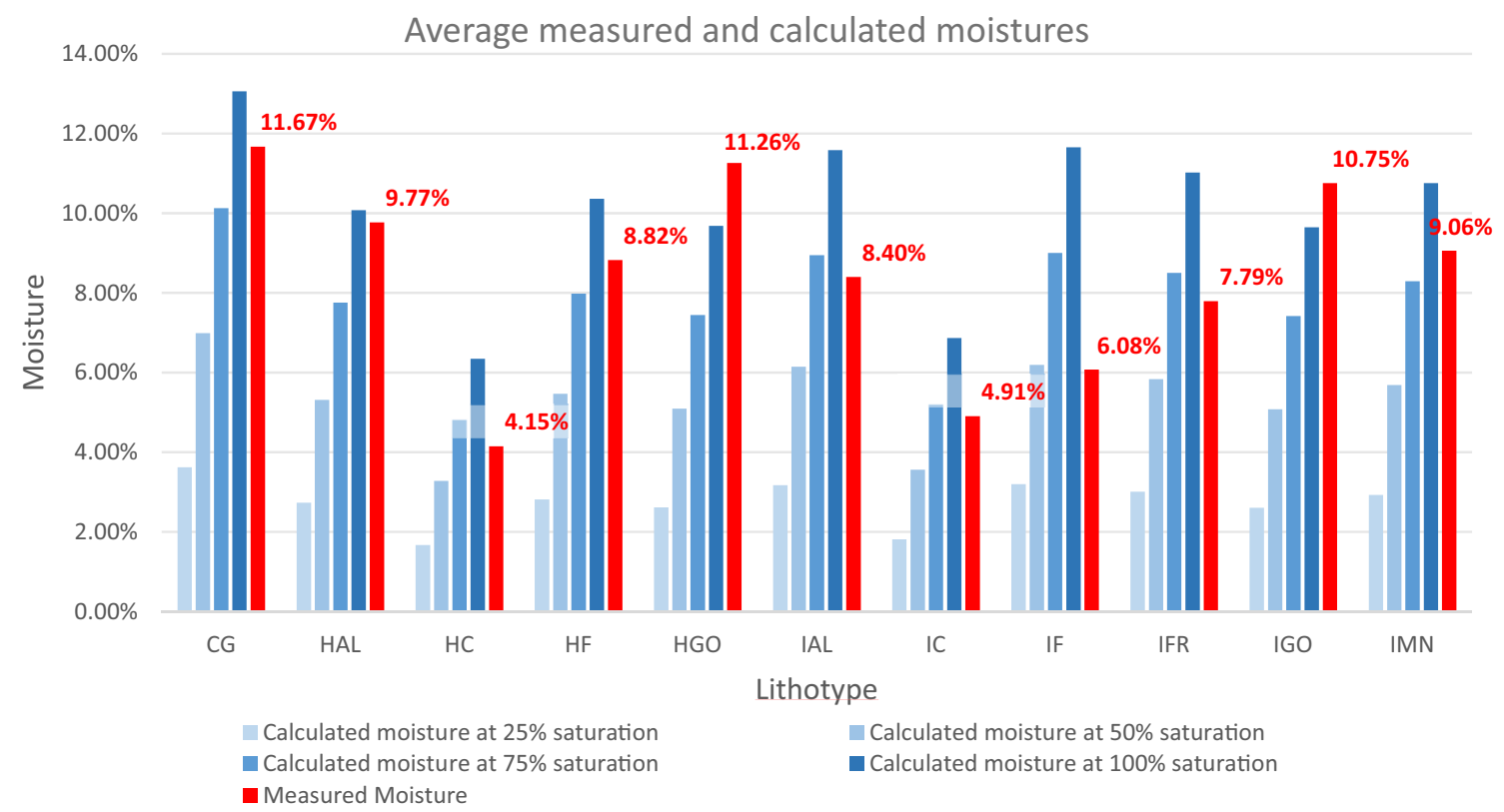

Fig. 8 Comparative plot of moistures calculated using MNC and those directly measured. Ore-type abbreviations: compact Itabirite (IC), soft itabirite (IF), goethite itabirite (IGO), aluminous itabirite

were Volume Fill and Sand Flask for friable materials and Volume Displacement for compact materials, taking into account $20-\mathrm{cm}$-long samples for which the values of natural density, moisture and calculated bulk density were determined. We applied the MNC to calculate the mineral density. Among the ore types, there are three groups in terms of porosity. They were separately modeled: compact ores (199 samples), soft ores (320 samples) and canga (60 samples). Figure 7 shows the graphs obtained for the three groups, which comprise samples from all three mines-i.e., Galinheiro, Pico and Sapecado. Compact ore presents two clusters, low-grade ore is unweathered itabirite and highgrade ore is compact hematite associated with hydrothermal enrichment. Linear regression equations were used as a basis to indirectly calculate the porosity of samples and for each block of the mineral-resource block model.

\subsection{Moisture analysis: direct measurement versus MNC}

Average values of directly measured moisture for each lithotype are compared with average moisture values for saturations of $25 \%, 50 \%, 75 \%$ and $100 \%$ that were obtained using MNC (Fig. 8).

Figure 8 indicates that measured moisture corresponds to approximately $50 \%$ of saturation for compact ores (HC and IC). For soft ores (HF, IF and IFR), measured moisture is close to calculated values of $75 \%$ saturation. Measured moisture values for contaminated and canga ores (CG,
(IAL), manganiferous itabirite (IMN), high-grade soft itabirite (IFR), soft hematite $(\mathrm{HF})$, compact hematite $(\mathrm{HC})$, goethite-hematite (HGO), aluminous hematite (HAL) and canga (CG)

HAL, HGO, IAL, IGO and IMN), especially goethite ores, are above $75 \%$ saturation or exceed $100 \%$ saturation. It can thus be concluded that porosity values are underestimated for those ore types. Figure 9 illustrates regression equations for porosity, distinguishing between contaminated and soft ore types. The angular coefficient of linear regression for contaminated ores is smaller and,

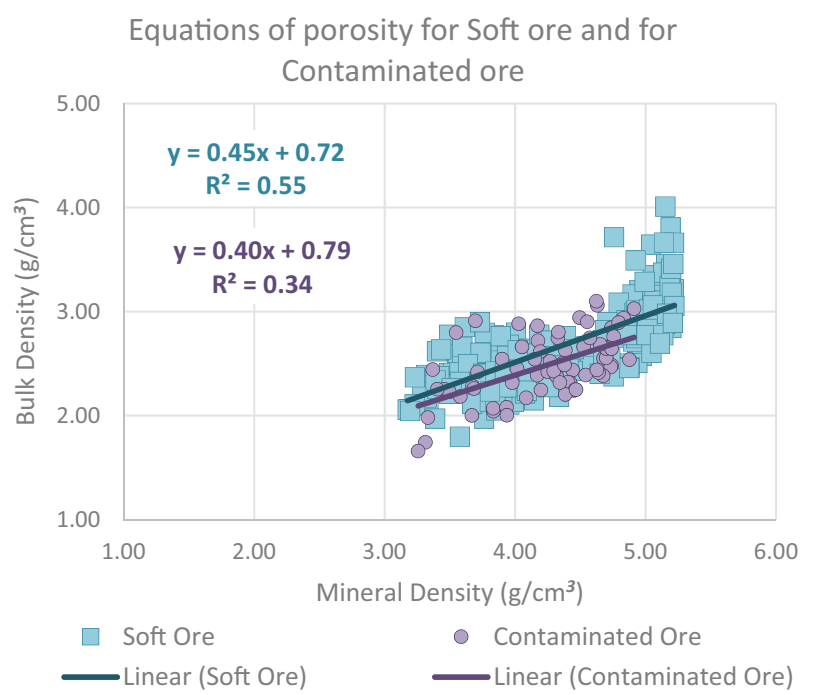

Fig. 9 Plot of mineral density versus bulk density for weathered samples. Regression equations are used to obtain the angular coefficient, which represents the porosity of soft and contaminated ores 


\section{Average estimated moisture and average measured moisture}

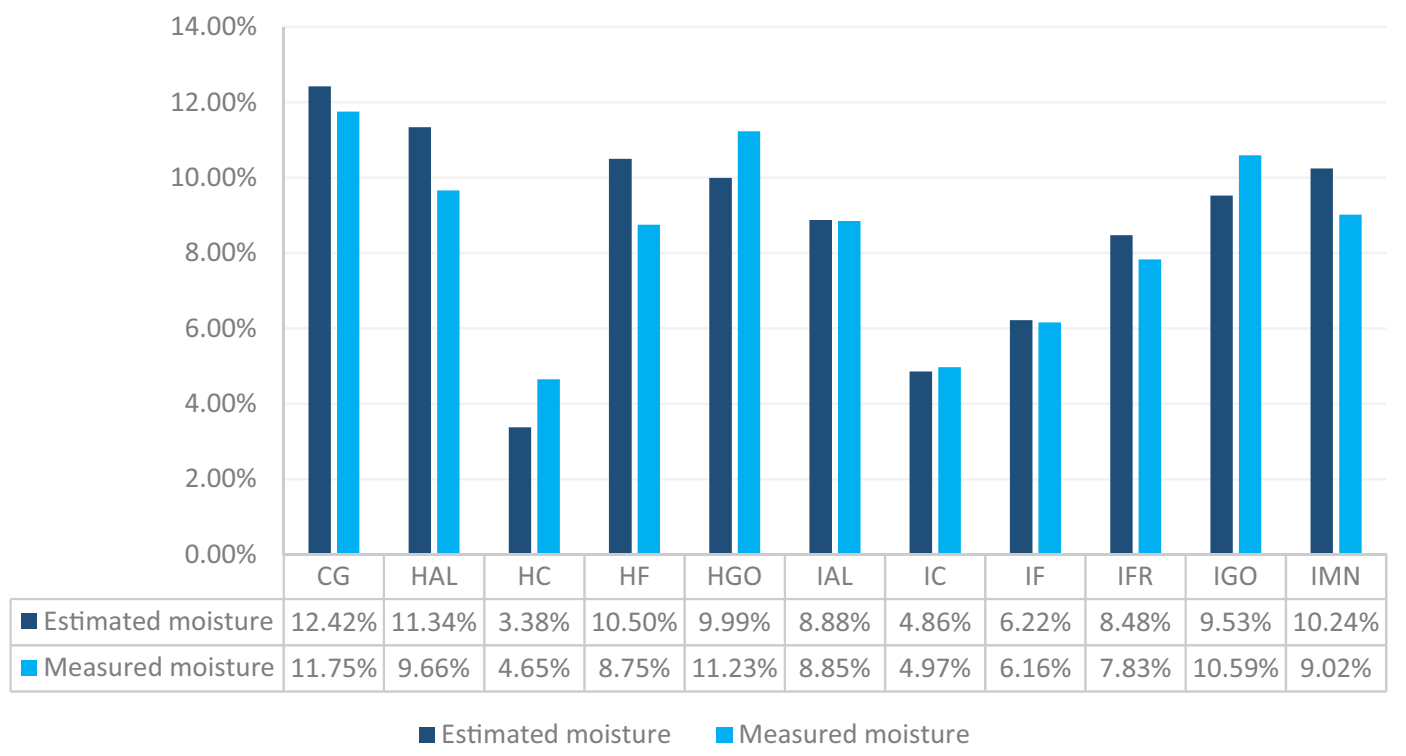

Fig. 10 Plot of average moisture values from direct measurements and MNC estimates. Ore-type abbreviations: compact Itabirite (IC), soft itabirite (IF), goethite itabirite (IGO), aluminous itabirite (IAL),

consequently, porosity is greater. Therefore, given that the equation used for both types of ore is the same, porosity is systematically underestimated in contaminated ores.

The problem of porosity underestimation was also faced by Braga [8], who pointed out the relevance of intracrystalline porosity, especially in contaminated itabirite ores. According to Braga [8], the total porosity of those itabirite ores may reach $60 \%$. Such a value considerably exceeds the theoretical upper limit of $47.5 \%$ porosity. This problem has been corrected in the present study by applying $98 \%$ saturation to those lithotypes. In addition to the porosity mathematically underestimated, other factors may contribute to the increase of moisture values, such as inappropriate chemical analyses, sampling errors (e.g., collect during rain or in a flooded place), and moisture from other sources. Our study indicates that a detailed investigation is needed to discover the causes of high moisture values and correct porosity and estimated moisture values applying MNC to contaminated ores.

The mineral-resource block model for Galinheiro mine generated in July 2020 was used to evaluate our results. Figure 10 shows a comparative graph of average moisture values for directly measured samples and for the block model (MNC estimate). There is a minor, but noticeable variation of $0.11 \%$ on average. The minimum difference is $0.02 \%$ and the maximum, $1.68 \%$. Figure 11 illustrates the correlation between estimated values and those obtained from direct measurement. There are deviations regarding the ideal correlation (dotted red line). However, the manganiferous itabirite (IMN), high-grade soft itabirite (IFR), soft hematite (HF), compact hematite (HC), goethite-hematite (HGO), aluminous hematite (HAL) and canga (CG)

values are distributed close to the trend of $45 \%$ with small deviations.

\subsection{Effect of seasonality}

Regression graphs and equations for the seasonality effect are shown in Fig. 12.

Due to the monthly fluctuation of canga and compact ores graphs, they were disregarded and those lithotypes

Annual average moisture of samples and estimated model

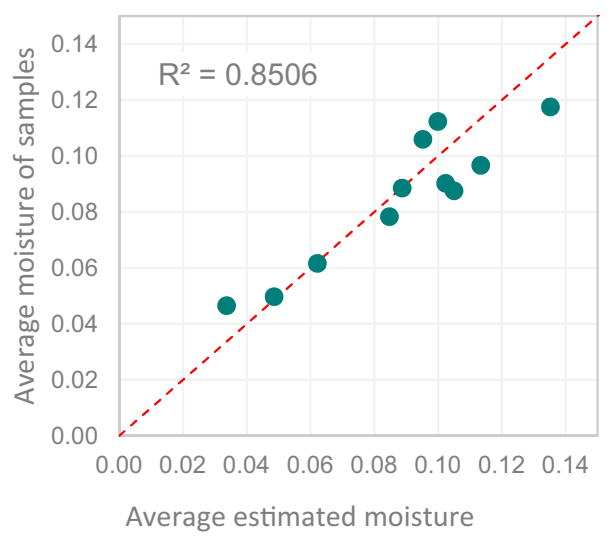

Fig. 11 Correlation between average moisture of samples and estimated average moisture 

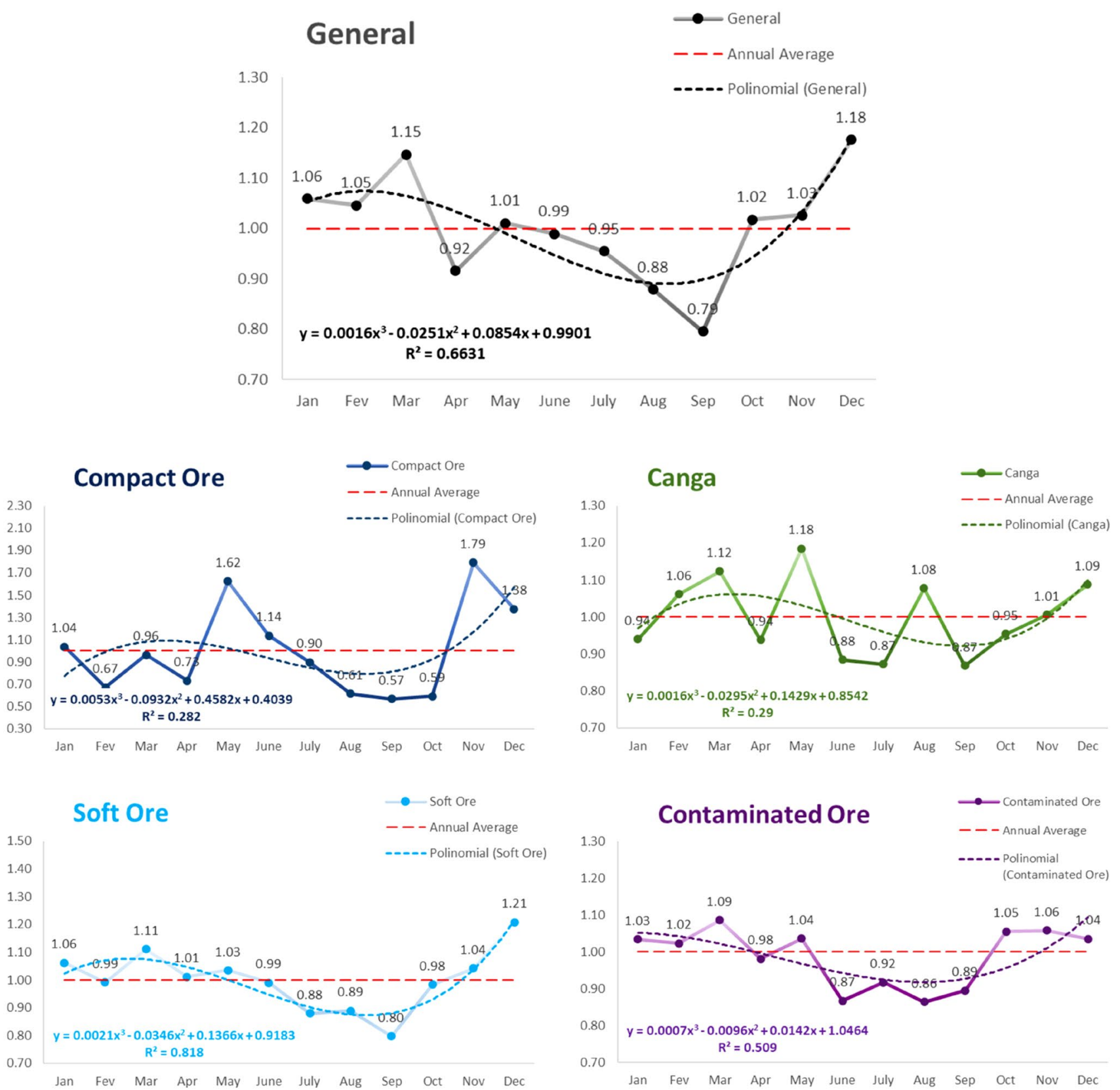

Fig. 12 Third-order polynomial regression graphs and equations to correct the seasonal effect per ore type. General stands for all samples. Variable $\mathrm{x}$ in the equation means the month of the year

were corrected according to the general regression equation (Fig. 12).

Figure 13 illustrates the seasonal effect correction in moisture estimated at the Galinheiro mine. The vertical bars represent the average moisture value according to the month of the year, separated by lithotype. Average monthly values are listed below the diagram for each ore type (Fig. 13). Compacted ores present low moisture values and are little influenced by the seasonal effect, while soft and contaminated ores and canga are highly influenced by the seasonal effect due to higher porosity and greater capacity to retain water. Moisture variations for weathered ores may exceed $2 \%$ along the year. The difference is enough to preclude beneficiation of some contaminated ore types during months of high rainfall.

More contaminated ores (HGO, IGO, IAL, HAL and IMN) are in the central area of the Galinheiro mine, while friable and compact itabirites are predominant in the area 
of North Galinheiro (Fig. 14a). Considering moisture estimates for the months of June and December (Fig. 14b, c), we notice that the area of central Galinheiro is very much affected by rainfall. It presents several regions with moisture values above the critical limit (12\%) in December, while in June moisture values are within acceptable limits. The area of North Galinheiro is little affected by rainfall. In June and December, the North Galinheiro iron ore shows moisture below the operational limit.

\section{Conclusions}

The method proposed herein provides valuable information that should be used to increase the predictability of planned moisture values at mine plan stages (daily, weekly, monthly, quarterly, and annual). Seasonal factors should not be applied to long-term resource models. For better effectiveness in terms of mine plans, it is important to consider the time of the year and iron-ore types. Although estimated values are in compliance with actual values from directly measured samples, we note that estimated values tend to be approximately $2 \%$ lower than the moisture value in the product (sinter feed at natural moisture). A correction of $2 \%$ can be applied, but we recommend that a more detailed study should be performed to check for sample moisture loss or moisture gain from different sources (e.g., water injections during material beneficiation to unclog chutes and screens, exposure to rainfall during transportation and low drainage at stockyards).

The critical limit of dry beneficiation plants at the Pico mine is $12.5 \%$, but considering the bias described above, it is recommended that moisture values in the plan never exceed $10.5 \%$. Being an indirect estimation method, its error is expected to be higher than the error derived from traditional methods, such as ordinary kriging, used to estimate chemical contents. As a precaution, it is suggested that planned moistures should be increased by $2 \%$ or maintained below $10.5 \%$. Therefore, it is possible to avoid or control recurrent problems in mineral beneficiation and in cargo transportation and shipment due to TML.

\section{Average moisture per lithotype with seasonal correction}

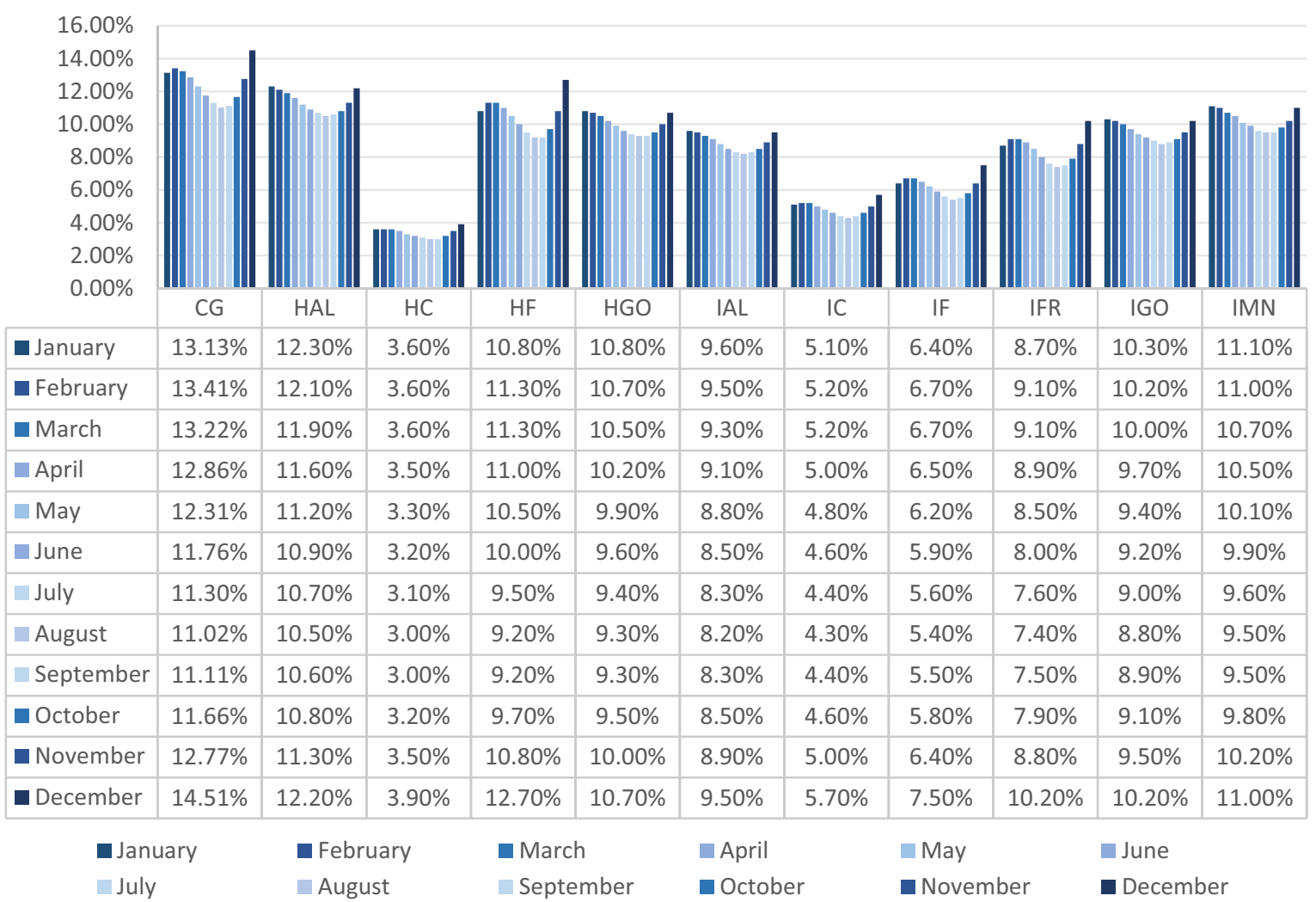

Fig. 13 Monthly diagram of the average estimated moisture value per ore type. Ore-type abbreviations: compact Itabirite (IC), soft itabirite (IF), goethite itabirite (IGO), aluminous itabirite (IAL), man- ganiferous itabirite (IMN), high-grade soft itabirite (IFR), soft hematite (HF), compact hematite $(\mathrm{HC})$, goethite-hematite (HGO), aluminous hematite (HAL) and canga (CG) 

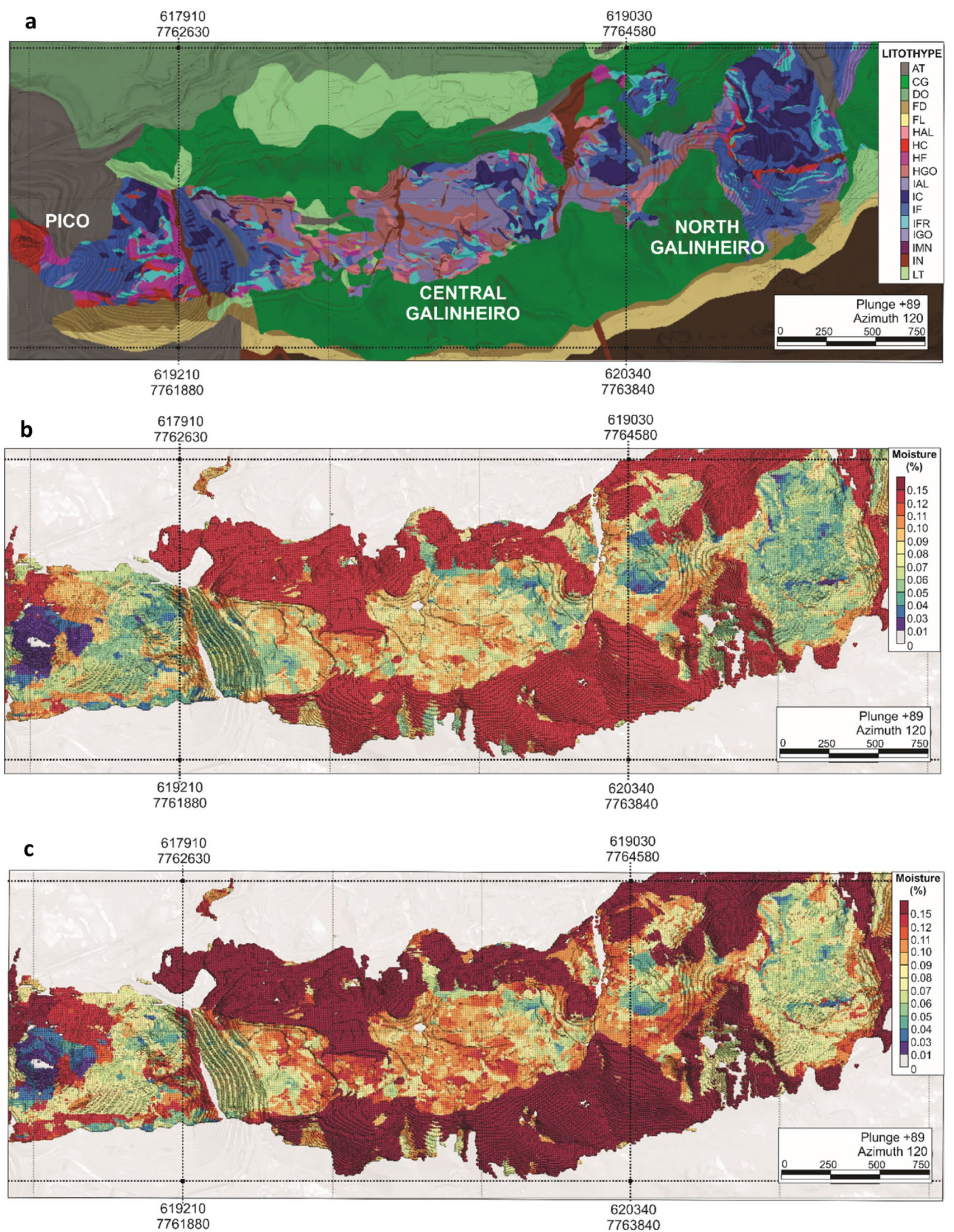
4Fig. 14 Simplified geological map of the Galinheiro mine (a) and moisture estimates for the months of June (b) and December (c). Lithotype abbreviations: compact itabirite ore (IC), soft itabirite ore (IF), goethite itabirite ore (IGO), aluminous itabirite ore (IAL), manganiferous itabirite ore (IMN), high-grade soft itabirite ore (IFR), soft hematite ore (HF), compact hematite ore $(\mathrm{HC})$, goethite hematite ore (HGO), aluminous hematite ore (HAL), canga ore (CG), dolomite (DO), phyllite (FL), dolomitic phyllite (FD), intrusive rocks (IN) and laterite (LT); Dump (AT)

\section{Financial interests}

Author Giulia Marina Cerqueira Dias receives a salary from Vale S.A, where she is works as Geologist. Author Diniz Ribeiro receives a salary from Vale S.A, where he is works as Specialist Geologist. Author Daniel Quinaud Rossi receives a salary from Vale S.A, where he is works as Coordinator of Local Geosciences.

Acknowledgements We are grateful to Vale S.A for providing financial support and all workmates who indirectly contributed to this work. We also are grateful to Carlos Spier, Alexandre Raphael Cabral and an anonymous reviewer for contributions and thought comments to improve the original manuscript.

Author Contributions Conceptualization, Diniz Ribeiro and Giulia Dias; methodology Giulia Dias, Diniz Ribeiro and Daniel Rossi; software, Giulia Dias; validation, Diniz Ribeiro and Daniel Rossi; data curation and analysis, Giulia Dias and Daniel Rossi; writing - original draft preparation, Giulia Dias; writing—review and editing, Diniz Ribeiro and Daniel Rossi; supervision, Diniz Ribeiro.

Funding Financial support for this study was provided by Vale S.A. This research received no external funding.

Availability of data and material The data used in this work belong to Vale S.A and cannot be widely distributed for corporate reasons.

Code availability The authors declare the possession of a legal license for all software applications used in this work, provided by Vale S.A.

\section{Declarations}

Conflict of interest The authors declare that they have no conflicts of interest regarding the publication of this paper.

Consent for publication All authors have read and agreed to the published version of the manuscript.

Ethical approval This study follows all ethical practices during writing.

Transparency The authors confirm that the manuscript is an honest, accurate, and transparent account of the study was reported; that no vital features of the study have been omitted; and that any discrepancies from the study as planned have been explained.

Open Access This article is licensed under a Creative Commons Attribution 4.0 International License, which permits use, sharing, adaptation, distribution and reproduction in any medium or format, as long as you give appropriate credit to the original author(s) and the source, provide a link to the Creative Commons licence, and indicate if changes were made. The images or other third party material in this article are included in the article's Creative Commons licence, unless indicated otherwise in a credit line to the material. If material is not included in the article's Creative Commons licence and your intended use is not permitted by statutory regulation or exceeds the permitted use, you will need to obtain permission directly from the copyright holder. To view a copy of this licence, visit http://creativecommons. org/licenses/by/4.0/.

\section{References}

1. Rosière CA, Spier CA, Rios FJ, Suckau VE (2008) The itabirites of the Quadrilátero Ferrífero and related high-grade iron ore deposits: an overview. Rev Econ Geol 15:223-254

2. Motta E, Moraes I, Apolônio P, Ribeiro D, Cunha Filho EM (2016) Incorporating mineralogical and density parameters in ferrous resource evaluation using mineralogical norm calculation MNC. In: Proceedings of the 24thWorld Mining Congress, Rio de Janeiro, Brazil, 18-21, 13, pp 209-221

3. Ribeiro DT (2004) Enriquecimento Supergênico de Formações Ferríferas Bandadas: Estruturas de Colapso e Desordem. Ph.D. Thesis, Federal University of the State of Rio de Janeiro, Institute of Geosciences, Post-Graduation Program in Geology, Rio de Janeiro, Brazil; 123p

4. Hensler AS, Hagemann SG, Rosière $C A$, Angerer T, Gilbert $S$ (2015) Hydrothermal and metamorphic fluid-rock interaction associated with hypogene "hard" iron ore mineralisation in the Quadrilátero Ferrífero, Brazil: implications from in-situ laser ablation ICP-MS iron oxide chemistry. Ore Geol Rev 69(2015):325-351

5. Hensler AS, Hagemann SG, Brown PE, Rosière CA (2014) Using oxygen isotope chemistry to track hydrothermal processes and fluid sources in BIF-hosted iron ore deposits in the Quadrilátero Ferrífero, Minas Gerais, Brazil. Mineralium Deposita 49 18:293-311

6. Dorr JVN (1969) Physiographic, stratigraphic and structural development of the Quadrilatero Ferrifero, Minas Gerais, Brazil. Geological survey professional paper 641-A. Washington, 1969. Disponível em: <https://pubs.usgs.gov/pp/0641a/report.pdf>

7. Davis, EG, Pinto, EJA, Pinto MCF (2005) Hidrologia. In: Projeto APA Sul RMBH Estudos do Meio Físico: área de proteção ambiental da região metropolitana de Belo Horizonte. Belo Horizonte: CPRM/SEMAD/CEMIG, 9

8. Cross W, Iddings JP, Pirsson LV, Washington HS (1902) A quantitative chemico-mineralogical classification and nomenclature of igneous rocks. J Geol 10:555-690

9. Braga DM (2019) Técnicas de análises de densidade e porosidade de minério de ferro por cálculo normativo mineralógico, microtomografia computadorizada, permoporosimetria e picnometria clássica: um estudo comparativo entre os métodos. Master Thesis. Post-Graduation in Metallurgical, Material and Mine Engineering. Federal University of Minas Gerais. 277p

10. Ribeiro D, Moraes I, Kwitko-Ribeiro R, Braga D, Spier C, Santos P (2020) From fresh itabirites and carbonates to weathered iron ore: mineral composition, density and porosity of different fresh and altered rocks from the Quadrilátero Ferrífero, Brazil. Minerals 2021(11):29. https://doi.org/10.3390/min11010029

Publisher's Note Springer Nature remains neutral with regard to jurisdictional claims in published maps and institutional affiliations. 